\title{
Conservation and pastoral value of former arable lands in the agro-pastoral system of the Alta Murgia National Park (Southern Italy)
}

\author{
Mariano Fracchiolla, ${ }^{1}$ Massimo Terzi, ${ }^{2}$ Francesco Saverio D’Amico, ${ }^{3}$ Luigi Tedone, ${ }^{1}$ \\ Eugenio Cazzato ${ }^{1}$
}

\begin{abstract}
${ }^{1}$ Department of Agricultural and Environmental Sciences, University of Bari; ${ }^{2}$ Institute of Biosciences and Bioresources, Italian National Research Council, Bari; ${ }^{3}$ Department of Biology, Botanical Garden Museum, University of Bari, Bari, Italy
\end{abstract}

\begin{abstract}
Grasslands are an important element of European landscapes and environment. In the last decades, several causes have contributed to their decline, among which the intensification of agriculture activities. The National Park of Alta Murgia represents a typical agro-pastoral karst system where the conversion to arable lands caused a drastic decline of semi-natural rocky grasslands of high naturalistic value that traditionally were used for sheep grazing. This change of land use created much concern about the lack of biodiversity and soil degradation. Thus, the Park Authority promotes reconversions of arable lands into grasslands to safeguard biodiversity, increase pastoralism and enhance the multi-functionality of farms. This study evaluates the conservation and pastoral value of plant communities in former arable lands derived from grasslands conversion (by crushing the rocky substrate) and subsequently abandoned. We selected seven sites of these abandoned arable lands, no longer ploughed or sown for three to five or twelve to fifteen years. In order to have a comparison with situations of low anthropic pressures, other five sites were selected in nearby natural rocky grasslands, without evidence of soil disturbance. Further two sites were selected in lands manually cleared
\end{abstract}

Correspondence: Mariano Fracchiolla, Department of Agricultural and Environmental Sciences, University of Bari, via Orabona 4, 70125 Bari, Italy.

E-mail: mariano.fracchiolla@uniba.it

Key words: Agro-pastoral systems; High nature value farmlands; Mediterranean rocky grasslands; Natural park; Stone crushing.

Acknowledgments: we would like to thank the anonymous referees for their useful suggestions and comments.

Received for publication: 17 October 2016.

Revision received: 31 January 2017.

Accepted for publication: 4 February 2017.

(C) Copyright M. Fracchiolla et al., 2017

Licensee PAGEPress, Italy

Italian Journal of Agronomy 2017; 12:847

doi:10.4081/ija.2017.847

This article is distributed under the terms of the Creative Commons Attribution Noncommercial License (by-nc 4.0) which permits any noncommercial use, distribution, and reproduction in any medium, provided the original author(s) and source are credited. from stones and taken out of crop production for more than fifty years. Vegetation samples were carried out according to the standard phytosociological method. Shannon and Richness indexes, ecological and phytogeographical quality and pastoral value were calculated. The ecological quality was calculated through the ratio between cover of diagnostic taxa of the higher syntaxonomic units characterising the undisturbed pastures and total cover. The phytogeographical value was evaluated considering the cover of endemic, sub-endemic and rare taxa out of the total cover value of each plant sample. For the calculation of pastoral value we considered the palatability of taxa on a scale ranging from 0 to 5 according to data found in scientific literature. From a conservation perspective, sites originated from the conversion of rocky pastures by crushing of the rocky surface showed marked differences from undisturbed grasslands, even after 15 years from abandonment. Lands manually cleared and abandoned for more than fifty years did not show appreciable differences from semi-natural grasslands, conserving many taxa of high conservation value. On the other hand, fields originated from grasslands conversion showed higher pastoral value. This paper emphasises the need for safeguarding the rocky substrates and their remnant typical grassland communities, even in the so-called quote. Results are useful for the sustainable management of the agro-pastoral system of Alta Murgia, taking into account the ecological and economic role of those lands whose rocky substrate had been crushed.

\section{Introduction}

Grasslands are an important element of landscapes of Europe and cover a significant proportion of territory although, during the centuries, they have reported expansions and reductions (e.g., Kaligarič et al., 2006). Most grasslands are the product of co-evolution with natural and anthropogenic disturbances associated with grazing, fire and farming. All these factors have shaped their biota and diversity that still remain today (Pärtel et al., 2005; Hopkins, 2009; Habel et al., 2013).

Grasslands have a basic role in feeding livestock species and provide important regulating ecosystem services (Smit et al., 2008). They can also mitigate soil erosion and pollution and provide a dense rooting system and a permanent soil cover. Moreover, grassland-based agroecosystems use lower levels of agro-chemicals than arable systems and they contribute to preserve cultural heritages (Bugalho and Abreu, 2008; Huyghe et al., 2014).

Dry grasslands, which include several vegetation classes (Rodwell et al., 2002), support a considerable proportion of biodiversity, holding up to 80 species $\mathrm{m}^{2}$ (Silva et al., 2008; Janišová et 
al., 2011; Habel et al., 2013; Vrahnakis et al., 2013). It has been calculated that nearly $50 \%$ of European endemic plants are dependent on the grassland habitat (Veen et al., 2009). According to the so-called Habitat Directive (Council Directive 92/43/EEC; European Commission, 1992) - that is the main tool for European nature conservation policy - several grassland types need to be safeguarded and require the establishment of special areas of conservation (SACs). Therefore, they play an important role within the EU Natura 2000 ecological network.

The EU defines permanent grasslands (including also permanent pastures) as land used to grow grasses or other herbaceous forage naturally (self-seeded) or through cultivation (sown) and that has not been included in the crop rotation of the holding for five years or longer (European Commission, 2011).

Permanent grasslands dominate agricultural landscapes in Ireland, the United Kingdom and the Netherlands. In most of the other European states, the share of grassland in the total area is between $18-33 \%$. Six countries are below this threshold such as Italy, Spain, Portugal and Greece (European Commission, 2012).

Based on Eurostat and Faostat dataset, Huyghe et al. (2014) reported that European grasslands have been significantly reduced during the last thirty years. Data concerning EU-18 reveal that, between 1961 and 2007, about 10 million of hectares of permanent grasslands (from 75.542 to 65.353 millions of hectares) were lost. Even data from Eurostat concerning EU-28 reveal in 2013 a further decline of grasslands from 2007, of approximately 5.7 millions of hectares (European Commission, 2016).

In Italy grassland areas covered about 5 millions of hectares in 1961, about 4.1 millions in 2007 (Huyghe et al., 2014) and about 3.3 millions in 2013 equal to about $27 \%$ of Total Utilized Agricultural Area (European Commission, 2016).

Several causes have contributed to grassland decline in Europe among which the intensification of agriculture activities and transformation of grasslands in arable lands (Habel et al., 2013).

Also in the northwestern part of Murge ridge (Alta Murgia, SE-Italy), a drastic decline of semi-natural rocky calcareous grasslands occurred, particularly between 80 s and 90 s. In fact, in this period, the availability of modern and powerful machineries allowed not only the clearing of lands - as it had traditionally been made in many territories of Southern Italy by manually removing stones to obtain more areas available for crops - but also scarification and crushing of the rocky substrate (called spietramento), drastically modifying the soil profile (Giglio et al., 1996; Moretti et al., 2004; Parise, 2012).

This lost of rocky grasslands created a lot of concern about the lack of biodiversity and soil degradation and led to the establishment of protected areas that stopped the conversion of the seminatural grasslands and started their active protection. The grasslands of the NW-Murgia are now included and protected by the National Park of Alta Murgia and within a site of community importance (SCI) and a special protection area (SPA). From data provided by the cartographic database of the Plan of the Alta Murgia National Park (Alta Murgia National Park Authority, 2014), it has been calculate that, within the Park territory, more than 25,000 ha of semi-natural grasslands present before 80 s were transformed in arable lands, that is the $37.0 \%$ of the total Park territory and the $56.0 \%$ of grasslands.

The Alta Murgia represents a typical Mediterranean agro-pastoral landscape and the rocky grasslands, traditionally used as extensive pastures for sheep and goats, are characterised by a high naturalistic value for their biodiversity, with many endemic and rare species (Bianco, 1962; Forte et al., 2005; Perrino et al., 2006; Terzi and Marvulli, 2006; Terzi et al., 2010). Therefore, the Alta
Murgia comprises high nature value (HNV) farmlands. The latter, as defined by Andersen et al. (2003), are areas where agriculture is a major (usually the dominant) land use and where that agriculture supports, or is associated with, either a high species and habitat diversity or the presence of species of European conservation concern, or both.

The conservation of biodiversity of these sites can be enhanced by low intensity farming practices (Paracchini et al., 2008; Schwaiger et al., 2012; Keenleyside et al., 2014). Traditional sheep farming would match well with the request of generating low impact on biodiversity as suggested, for example, by Osterman (1998) for European Natura 2000 sites and, particularly, by Moretti et al. (2016) for the case study of Alta Murgia.

In compliance with the above-mentioned principles and with the purpose of protecting natural and cultural heritage, as requested by Italian Law for protected areas 394/91, the Alta Murgia National Park Plan promotes reconversion of arable lands in grasslands. Such action is supposed to increase the pastoralism, to promote extensive agricultural practices and to enhance the multifunctionality of farms within the Park territories (Alta Murgia National Park Authority, 2014).

Many studies have dealt with old-fields successions in the Mediterranean Region (see Plieninger et al., 2014 for a revision on this topic) coping with the phenomena of rural land abandonment and consequent recovery of natural vegetation. The effects of rocky grasslands transformation by crushing the substrate have been only partially studied. In the Alta Murgia, these effects were investigated for their implications on soil water balance and erosion (Giglio et al., 1996; Moretti et al., 2004; Canora et al., 2008, 2009) and only preliminary data about floristic composition are available (Fracchiolla and Tedone, 2009). Therefore, the aim of this paper was to evaluate the pathway of re-development of seminatural grasslands on former arable lands (derived from grasslands conversion by crushing the rocky substrate with powerful machineries and subsequently excluded from crop growing) and evaluate their ecological and pastoral value.

\section{Materials and methods}

\section{The study area}

The Murge ridge lies in the C-Apulia and E-Basilicata Regions, in the SE-Italy. The north-western part of Murge - the socalled Alta Murgia - stretches between the Bradanic valley and the Adriatic coast, reaching the highest elevation at Monte Caccia, at nearly $700 \mathrm{~m}$ asl.

Established in 1998 and officially proclaimed National Park in 2004, the Alta Murgia National Park covers a total area of nearly 68,000 ha (Figure 1). According to the bioclimatic classification system of Rivas Martinez (2008), the bioclimate of Altamura, the largest municipality by land area of the Park territory, is Mediterranean pluvio-seasonal oceanic of semi-continental type and with a mesomediterranean thermotype and a dry ombrotype (Terzi and D'Amico, 2016).

The geological substrate consists of a thick layer of JurassicCretaceous carbonate sedimentary rocks and only on alternate and discontinuous tracts it is covered by thin Plio-Pleistocene deposits. The territory represents a typical Mediterranean karst landscape, slightly corrugated, and cut by shallow or deep karst valleys (Ricchetti et al., 1988).

According to the first level of Corine Land Cover 
Classification, the territory of the Park is composed of agricultural areas (33,399 ha), forest and semi-natural areas (33,421 ha), artificial surfaces (1211 ha) and water bodies ( 8 ha) (Alta Murgia National Park Authority, 2014).

The semi-natural areas include large expansions of dry rocky grasslands dominated by Stipa austroitalica Martinovsky and classified within the endemic Acino suaveolentis-Stipetum austroitalicae Forte and Terzi 2005 of the Hippocrepido glaucae-Stipion austroitalicae (Forte et al., 2005). These grasslands are subjected to extensive grazing by sheep and goats and they were used until $19^{\text {th }}$ century as winter pastures along the transhumance routes from the Apennine to lowlands (Castoro et al., 1997).

Owing to the occurrence of these grasslands, together with other habitats and species of conservation interest, the northwestern part of the Murge hill was also recognised as a SCI and SPA, thus concurring at the European network Natura 2000 (Perrino and Wagensommer, 2013). Among the grassland habitats listed in the 92/43/EEC Directive, three types were identified in the Alta Murgia National Park: habitat 6210 Semi-natural dry grasslands and scrubland facies on calcareous substrates (FestucoBrometalia) (*important orchid sites), habitat 6220 Pseudo-steppe with grasses and annuals of the Thero-Brachypodietea* and habitat 62A0 Eastern sub-Mediteranean dry grasslands (Scorzoneratalia villosae).

\section{Data collection and statistical treatment}

Along a vegetation belt comprised between 340 and $590 \mathrm{~m}$ asl on the Adriatic side of the Alta Murgia National Park, we selected seven sites of former arable lands, derived from semi-natural grasslands (Figure 2), converted into arable lands by stone clearing and crushing the karst surface (Figure 3), and no longer ploughed or sown for three-five or twelve-fifteen years. The sites were identified on the basis of direct consultations with farmers and landowners in order to obtain reliable information about the agronomic history of the lands. The sites were indicated with the tag $\mathrm{C}$ (i.e. crushed substrate) followed by the number of years from the stopping of cultivation (C3, C5, etc.). The four sites where the cultivation was stopped since 3 or 5 years were on the whole indicated as $\mathrm{Cr}$ (recently abandoned lands) and the others, where the cultivation was stopped since 12 or 15 years, as Co (older abandoned lands). Other five surveys were carried out in nearby natural rocky grasslands without any evidence of recent or ancient soil disturbance. Based on the expert knowledge of three of the authors (MF, MT and SD) that have already been involved in studies about the vegetation of the Alta Murgia, other five sites were selected with the purpose of recording the natural variability (e.g., altitude, rockiness, plant cover) of semi-natural grasslands in the study area (Figure 2). The sites were labelled with the tag $\mathrm{G}(\mathrm{Ga}, \mathrm{Gb}$, etc.). In order to have a comparison with situations of low anthropic pressures other two sites were selected. These are ancient former arable lands, manually cleared from stones without crushing karst surface, that were been taken out of crop production for more than fifty years. These sites were small portions of fields (the so-called quote) redistributed to farmers after the Second World War according to the Italian land reform. These two sites were labelled as Aa and $\mathrm{Ab}$ (Ancient former arable lands) (Figure 4).

Location of all 14 sites is reported in Figure 1; they lie within a restricted area characterised by relatively homogeneous bioclimatic conditions (Macchia et al., 2000). Both these last sites (Aa and $\mathrm{Ab}$ ) and the semi-natural grasslands were characterised by shallow soils lacking well-defined horizons (lithosols) on a calcareous substrate (Source: Geographical Information System of the Alta Murgia National Park). Soils originated by grassland con-

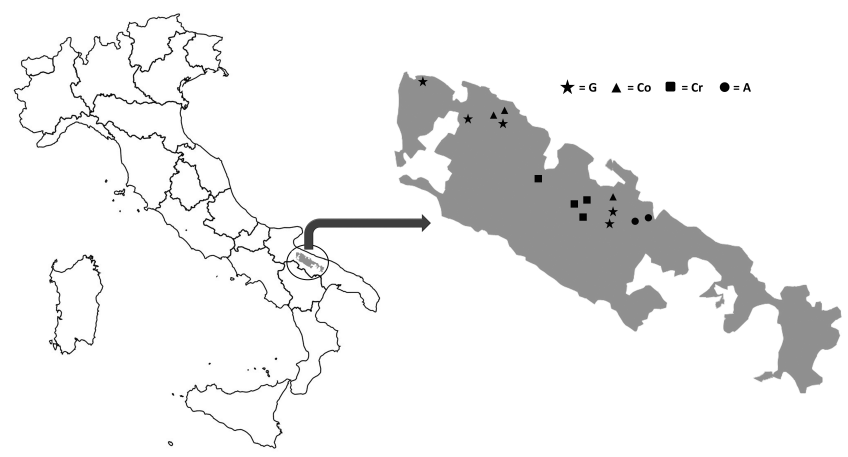

Figure 1. Study area and localisation of the samples: the shaded area corresponds to the National Park of Alta Murgia. $\mathrm{Cr}=\mathbf{s a m}$ ples on former arable lands, derived from semi-natural grasslands, converted into arable lands by stone crushing, and no longer ploughed or sown for 3-5 years; $\mathrm{Co}=$ samples on former arable lands, derived from semi-natural grasslands through stone crushing, and no longer ploughed or sown for 12-15 years; $\mathrm{G}=$ samples on Mediterranean semi-natural rocky grasslands; $A=$ samples on ancient former arable lands, manually cleared from stones and taken out of crop production for more than fifty years.

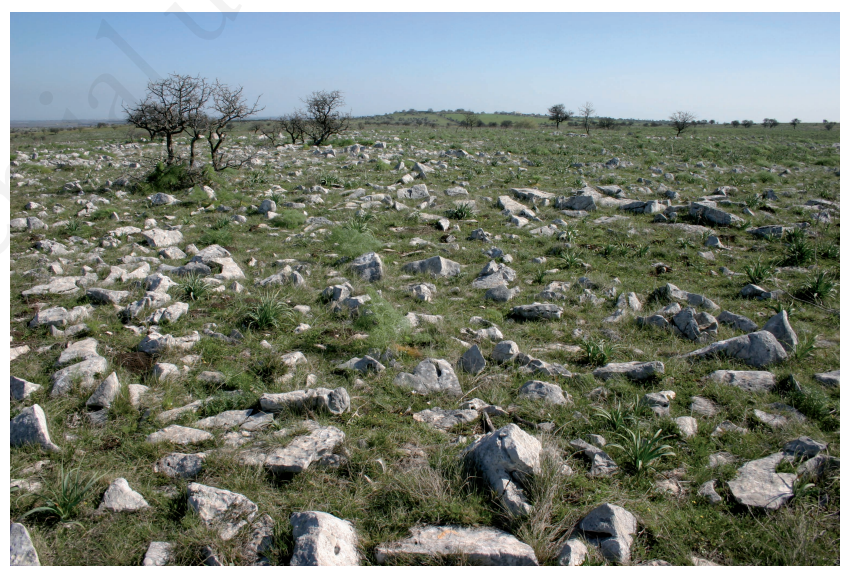

Figure 2. Semi-natural grasslands (rocky pastures).

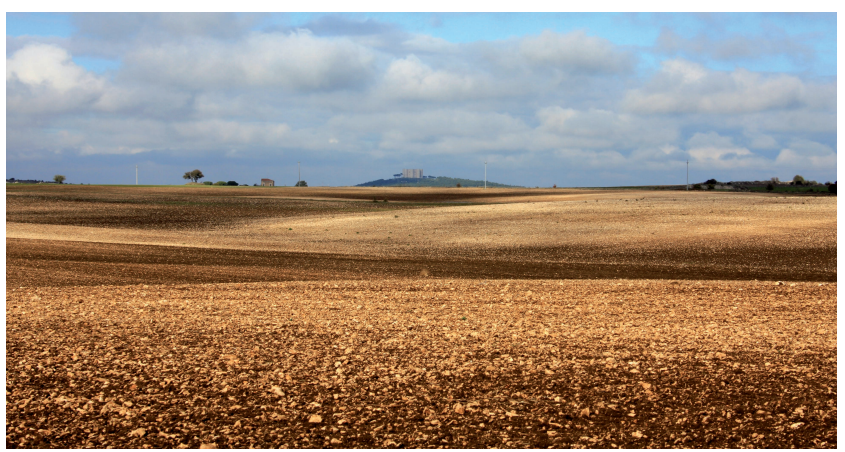

Figure 3. Effects of transformation of semi-natural rocky grasslands: arable lands derived from rocky substrate crushing by powerful machineries. 
version were characterised by coarse rock fragments $(6-20 \mathrm{~cm})$ with high porosity and higher specific surface than the original karstic surface texture. Their attitude to cereal cultivation, even though with scarce yields, were made possible by the presence of fine particles represented by the original terra rossa and allochthonous soils (Canora et al., 2008).

According to the guidelines of soil description (FAO, 2006), both the sites $\mathrm{G}$ and A belonged to the class $\mathrm{F}$ ( $\mathrm{Few}$ ) for rock outcrops (2-5\% of surface coverage) and to the class V (Very few) for course surface fragments $(0-2 \%$ of surface coverage). Sites labelled with the tag $\mathrm{C}$ belonged to the class $\mathrm{N}$ (None) for rock outcrops ( $0 \%$ of surface coverage) and to the class M (Many) for course surface fragments ( $15-40 \%$ of the surface coverage). All the sites belonged to the class 01 in terms of slope gradient $(0-0.2 \%)$ except $\mathrm{Gd}$ and $\mathrm{Ge}$ that were in class $(07$ and 08$)(10 \%$ expositions $\mathrm{N}$ and $20 \%$ exposition $\mathrm{W}$ respectively).

Between May and June of 2008 (C3), 2009 (C4a, C4b, C5, C15a, C15b, Ga, Gb, Gc, Aa, Ab), 2010 (Gd, Ge) and 2013 (C12), a vegetation sampling was carried out according to the standard phytosociological method of Braun-Blanquet (1932). A standard plot size of $100 \mathrm{~m}^{2}$ was used for all the samples, selected away from trees, stonewalls or other elements that could make not homogenous the area. The species cover-abundance values were recorded according to the original Braun-Blanquet scale, but they were converted into the ordinal scale proposed by van der Maabel (1979) for the classification and ordination of the samples.

Taxonomic nomenclature refers to Euro+Med (2006) and for missing taxa to Conti et al. (2005). The data matrix, consisting of 14 samples x 227 taxa, was classified by using the unweighted pair-groups method with arithmetic mean (UPGMA) on a Chord distance matrix. The method is space conserving and has been suggested as a good choice for community data (McCune and Grace, 2002). The floristic relationships among the main clusters of samples were visualised by means of nonmetric multi-dimensional scaling (NMDS) with the Chord distance. Classification and ordination were carried out by using the Pc-Ord 6.19 software (McCune and Mefford, 2011). For the NMDS, the slow and thorough autopilot mode in Pc-Ord was selected.
Diversity of each sample was calculated through the number of species (richness) and the Shannon index. In order to assess the ecological quality of diversity, other two indexes - called syntaxonomic index (DT index) and phytogeographical index (ER index) - were considered. The first one is calculated as the sum of the Specific Contribute (SC) of the diagnostic taxa of the higher syntaxonomic units (Hippocrepido-Stipion, Euphorbietalia myrsinitae and Festuco-Brometea) characterising the undisturbed rocky pastures: $\mathrm{DT}=\Sigma \mathrm{SC} i_{\text {DT }}$.

$\mathrm{SCi}$ represents the Specific Contribute, which is the ratio of the percent cover value of the $i$ - species and the sum of the percent cover values of all the taxa in the sample (i.e., the total percent cover value). The percent cover value is the mean cover degree of the Braun-Blanquet scale as indicated by Mueller-Dombois and Ellenberg (1974). In the case of $\mathrm{SCi}_{\mathrm{DT}}$, the numerator refers only to the diagnostic species (DT in Appendix Table 1) of higher syntaxonomic units as listed by Terzi et al. (2010) and Terzi and

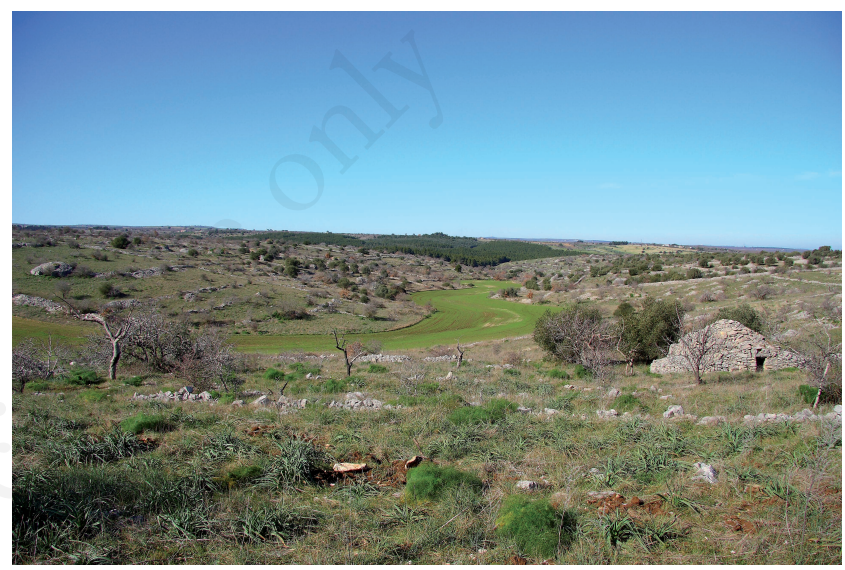

Figure 4. Ancient former arable lands manually cleared from stones and taken out of crop production for more than fifty years (so-called quote) on the slopes of the karst valley. The bottom of the valley is cultivated.

Table 1. Altitude of the sites surveyed and land use within the radius of $500 \mathrm{~m}$.

\begin{tabular}{|c|c|c|c|c|c|c|c|c|c|c|}
\hline Clusters $^{\circ}$ & Samples & Altitude & $\begin{array}{l}\text { Semi-natural } \\
\text { grasslands }\end{array}$ & $\begin{array}{l}\text { Land } \\
\text { Arable } \\
\text { lands }\end{array}$ & $\begin{array}{l}\text { use within } \\
\text { Almond } \\
\text { orchards }\end{array}$ & $\begin{array}{l}\text { the radius of } 5 \\
\text { Former } \\
\text { arable lands }\end{array}$ & $\begin{array}{l}0 \mathrm{~m} \text { (\% share } \\
\text { Ancient } \\
\text { former } \\
\text { arable lands } \\
\text { (quote) }\end{array}$ & $\begin{array}{l}\text { of the total } \\
\text { Artificial } \\
\text { coniferous } \\
\text { forests }\end{array}$ & $\begin{array}{l}\text { urface) } \\
\text { Natural } \\
\text { forests }^{\circ}\end{array}$ & $\begin{array}{l}\text { Roads and } \\
\text { buildings }\end{array}$ \\
\hline $\mathrm{Cr}$ & $\begin{array}{c}\text { C3 } \\
\text { C4a } \\
\text { C4b } \\
\text { C5 }\end{array}$ & $\begin{array}{l}560 \\
590 \\
550 \\
550\end{array}$ & $\begin{array}{l}70.6 \\
61.8 \\
71.8 \\
34.0\end{array}$ & $\begin{array}{l}17.6 \\
24.5 \\
16.6 \\
22.9\end{array}$ & $\begin{array}{l}0.0 \\
0.0 \\
0.0 \\
0.2\end{array}$ & $\begin{array}{c}8.1 \\
12.4 \\
8.1 \\
33.1\end{array}$ & $\begin{array}{l}0.0 \\
0.0 \\
0.0 \\
0.0\end{array}$ & $\begin{array}{l}0.0 \\
0.0 \\
0.0 \\
8.3\end{array}$ & $\begin{array}{l}0.0 \\
0.2 \\
0.0 \\
0.4\end{array}$ & $\begin{array}{l}3.7 \\
1.2 \\
3.6 \\
1.0\end{array}$ \\
\hline $\mathrm{Co}$ & $\begin{array}{l}\text { C12 } \\
\text { C15a } \\
\text { C15b }\end{array}$ & $\begin{array}{l}480 \\
394 \\
394\end{array}$ & $\begin{array}{l}59.9 \\
58.2 \\
56.8\end{array}$ & $\begin{array}{c}29.1 \\
7.0 \\
7.6 \\
\end{array}$ & $\begin{array}{l}3.2 \\
8.3 \\
7.6\end{array}$ & $\begin{array}{c}5.1 \\
15.3 \\
15.3 \\
\end{array}$ & $\begin{array}{l}0.0 \\
0.0 \\
0.0\end{array}$ & $\begin{array}{l}0.0 \\
0.0 \\
0.0\end{array}$ & $\begin{array}{l}0.2 \\
6.4 \\
8.2\end{array}$ & $\begin{array}{l}2.5 \\
4.8 \\
4.5\end{array}$ \\
\hline A & $\begin{array}{l}\mathrm{Aa} \\
\mathrm{Ab}\end{array}$ & $\begin{array}{l}470 \\
430\end{array}$ & $\begin{array}{l}0.0 \\
0.0\end{array}$ & $\begin{array}{c}5.1 \\
28.0\end{array}$ & $\begin{array}{c}33.1 \\
0.0\end{array}$ & $\begin{array}{l}0.0 \\
0.0\end{array}$ & $\begin{array}{l}55.6 \\
71.3\end{array}$ & $\begin{array}{l}5.1 \\
0.0\end{array}$ & $\begin{array}{l}0.3 \\
0.6\end{array}$ & $\begin{array}{l}0.8 \\
0.0\end{array}$ \\
\hline $\mathrm{G}$ & $\begin{array}{l}\mathrm{Ga} \\
\mathrm{Gb} \\
\mathrm{Gc} \\
\mathrm{Gd} \\
\mathrm{Ge}\end{array}$ & $\begin{array}{l}560 \\
570 \\
411 \\
488 \\
343 \\
\end{array}$ & $\begin{array}{l}55.2 \\
58.5 \\
59.0 \\
83.3 \\
74.9 \\
\end{array}$ & $\begin{array}{c}44.6 \\
41.4 \\
7.6 \\
12.1 \\
10.8\end{array}$ & $\begin{array}{c}0.0 \\
0.0 \\
5.1 \\
0.0 \\
12.7\end{array}$ & $\begin{array}{c}0.0 \\
0.0 \\
15.3 \\
0.0 \\
0.0\end{array}$ & $\begin{array}{l}0.0 \\
0.0 \\
0.0 \\
0.0 \\
0.0\end{array}$ & $\begin{array}{l}0.0 \\
0.0 \\
0.0 \\
0.0 \\
0.0\end{array}$ & $\begin{array}{l}0.3 \\
0.1 \\
8.4 \\
4.1 \\
0.0\end{array}$ & $\begin{array}{l}0.0 \\
0.0 \\
4.6 \\
0.5 \\
1.5\end{array}$ \\
\hline
\end{tabular}

$\mathrm{Cr}$, former arable lands, derived from semi-natural grasslands, converted into arable lands by stone crushing, and no longer ploughed or sown for 3-5 years; Co, former arable lands, derived from semi-natural grasslands through stone crushing, and no longer ploughed or sown for 12-15 years; A, ancient former arable lands, manually cleared from stones taken out of crop production for more than fifty years; G, Mediterranean semi-natural rocky grasslands. ${ }^{\circ}$ Areas with presence of oaks, greater than $1000 \mathrm{~m}^{-2}$ and with tree-crown density $>40 \%$. 
D'Amico (2016). The syntaxonomic index indicates the floristic proximity of a disturbed site to the typical semi-natural grasslands (in this case of the Hippocrepido-Stipion).

The phytogeographical index was calculated in a similar way of the syntaxonomic index but summing the SC of the endemic, sub-endemic and rare species occurring in a relevé: $\mathrm{DT}=\Sigma \mathrm{SCi}_{\mathrm{ER}}$.

The species of high phytogeographical value were selected on the basis of the chorological information from Pignatti (1982) and evaluations based on several bibliographic data (ER in Appendix Table 1). Pastoral value (PV) was calculated by using the formula given by Daget and Poissonet (1969) and reported by Roggero et al. (2002): $\mathrm{PV}=0.2 \times \Sigma \mathrm{SCi} \times \mathrm{SIi}$. The specific index (SI) is based on a discrete scale indicating increasing palatability: $5=$ excellent forage plant; $4=$ very good forage plant; $3=$ good forage plant; $2=$ poor forage plant; $1=$ occasionally grazed; $0=$ ungrazed and/or toxic plant (Bagella and Roggero, 2004). It was assigned to each taxon according to its grazing value as reported for Italy and Apennine by Roggero et al. (2002). For missing taxa, data reported by same authors for other localities (Roggero et al., 2002) or by Forte and Vita (1999) were considered. In few cases, the SI value was chosen according to our experience and interviews to local breeders. In order to visualise the strength of the relationships among the NMDS ordination scores and life-forms spectra, diversity (Richness and Shannon indexes), syntaxonomic and phytogeographical indexes, pastoral value and percentage covers of the main land-uses around the samples, joint plots with an $\mathrm{r}^{2}$ cut-off of 0.30 were used (McCune and Grace, 2002). The main land-uses around each sample, in a circular area with a diameter of $1 \mathrm{~km}$, were recorded as cover percentages by using Google Earth Pro (Table 1). Life-form spectra of samples were calculated on the basis of life-form information provided in Pignatti (1998), as the percentage of the number of taxa of every life form out of the total number of taxa in that sample.

\section{Results and discussion}

The dendrogram (Figure 5) showed three main clusters of samples. The first one (cluster $\mathrm{Cr}$ ) - separated from all the others included samples representing former arable lands on crushed substrate, not cultivated from 3-5 years (samples C3 to C5). Within this cluster, the sample $\mathrm{C} 3$ turned out to be quite differentiated from the others. The second cluster $(\mathrm{Co})$ grouped the samples done on former arable lands on crushed substrate, where the cultivation had been stopped from 12-15 years (samples $\mathrm{C} 12$ to $\mathrm{C} 15$ ). The remaining samples were included in the third cluster (cluster AG) that was in turn subdivided into two sub-clusters separating the semi-natural grasslands (cluster $\mathrm{G}$ ) from the ancient traditional cultivations (cluster A).

In the NMDS ordination, the auto pilot mode of Pc-ord selected a two-axes solution with a minimum stress of 9.67, indicating a good ordination (McCune and Grace, 2002). The proportion of variance represented by the two axes were 68.3 and $15.1 \%$, respectively, explaining $83.4 \%$ of total variation.

The three main clusters $(\mathrm{Cr}, \mathrm{Co}$ and $\mathrm{AG})$ described above, turned out to occupy different parts of the NMDS ordination diagram (Figure 6). The recently abandoned lands $(\mathrm{Cr})$ are placed on the right side of axis 1 ; on the opposite side, there are the rocky pastures $(G)$ and the samples of cluster A. Samples on former arable lands abandoned for 12-15 years are in the middle and also differentiated on axis 2 . Thus, the axis 1 - which accounts for the most part of the variance - represents an anthropogenic distur-
Information remaining (\%)

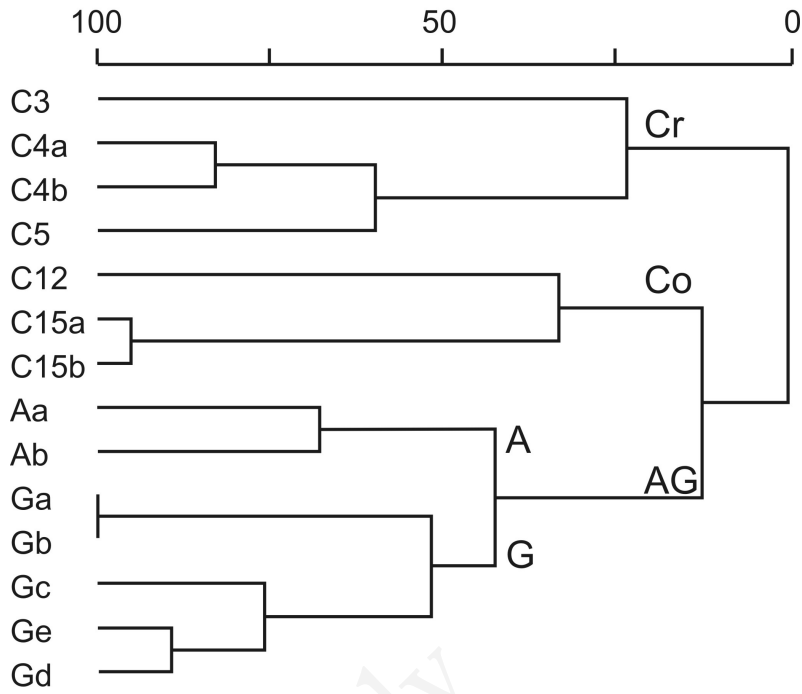

Figure 5. Unweighted pair-groups method with arithmetic mean clustering (chord distance) of samples. $\mathrm{Cr}=$ samples on former arable lands, derived from semi-natural grasslands, converted into arable lands by stone crushing, and no longer ploughed or sown for 3-5 years; $\mathrm{Co}=$ samples on former arable lands, derived from semi-natural grasslands through stone crushing, and no longer ploughed or sown for 12-15 years; $G=$ samples on Mediterranean semi-natural rocky grasslands; $A=$ samples on ancient former arable lands, manually cleared from stones and taken out of crop production for more than fifty years.

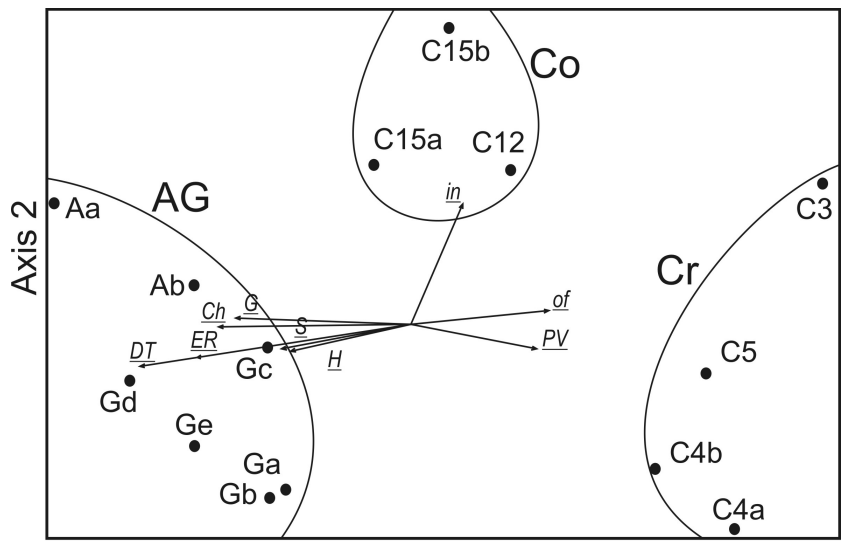

Axis 1

Figure 6. Nonmetric multi-dimensional scaling ordination diagram. Cr=samples on former arable lands, derived from semi-natural grasslands, converted into arable lands by stone crushing, and no longer ploughed or sown for 3-5 years; $\mathrm{Co}=$ samples on former arable lands, derived from semi-natural grasslands through stone crushing, and no longer ploughed or sown for 1215 years; $G=$ samples on Mediterranean semi-natural rocky grasslands; $A=$ samples on ancient former arable lands, manually cleared from stones and taken out of crop production for more than fifty years; $\mathrm{G}=$ geophytes; $\mathrm{Ch}=$ chamaephytes; $\mathrm{ER}=$ phytogeographical index; DT=syntaxonomic index; $S=$ richness index; $\mathbf{H}=$ Shannon index; $\mathbf{P V}=$ pastoral value index; of $=$ cover percentage of former arable lands (old-fields) around the samples; in=cover percentage of roads and buildings (infrastructures) around the samples. 
bance gradient, with the less disturbed pastures on the left side.

The relationships among ordination scores and biological and environmental variables showed positive correlations of axis 1 with pastoral value index $\left(\mathrm{r}^{2}=0.33\right)$ and percentage of old-fields around the samples $\left(\mathrm{r}^{2}=0.30\right)$. Negative correlations were recorded with richness $\left(r^{2}=0.31\right)$, Shannon diversity index $\left(r^{2}=0.33\right)$, phytogeographical index $\left(\mathrm{r}^{2}=0.56\right)$, syntaxonomic index $\left(\mathrm{r}^{2}=0.70\right)$, geophytes $\left(r^{2}=0.45\right)$ and chamaephytes $\left(r^{2}=0.50\right)$. Moreover, there was a positive correlation between axis 2 and percentage of infrastructures (e.g., buildings, roads) around the samples $\left(\mathrm{r}^{2}=0.30\right)$. The relationships among the NMDS axes scores and the diversity indexes or the percentages of therophytes were affected by sample C3. The occurrence and abundance of Onopordum illyricum in this sample indicate different ecological conditions from the other samples, maybe due to higher grazing intensity. The cluster $\mathrm{Cr}$ turned out to be differentiated by the higher percentage of therophytes (Table 2) when the analysis was repeated without the sample C3 (data not shown).

Other studies concerning secondary successions after crop abandonment in the Mediterranean Basin have documented an increase of pioneering annual and biennial plants during the first stage of colonisation of abandoned croplands (Debussche et al., 1996; Bonet and Pausas, 2007). In the following stages of the succession, the more competitive woody species prevail, the earlier pioneering plants (mostly therophytes) disappear and the total richness decreases. In Mediterranean old-fields, plant richness is considered to be varying with time according to a hump-shaped curve, with a maximum in the first stage, after abandonment, and with a subsequent decline in the following stages of the succession (Bonet and Pausas, 2007). However, some exceptions to this general pathway have been recorded both in Mediterranean and nonMediterranean environments (Prévosto et al., 2011; Plieninger et al., 2014). Our findings (with the exception of the sample C3) confirmed the increase of therophytes in the first stage of succession after abandonment. However, after this stage, we did not observed an increase of phanerophytes (woody plants) nor a decline of total plant richness. This inconsistency could be due to the fact that the semi-natural grasslands of Alta Murgia are a relatively stable ecosystem. A phytohistorical study of C-Apulia documented their occurrence, at least in some parts of the NW-Murge ridge, since the pre-Roman age (Amico, 1954). Pirini et al. (2014) discussed about primary and secondary grasslands in lower belts of the $\mathrm{N}$ Mediterranean Basin and hypothesised the persistence of relict steppe-like grasslands throughout postglacial times in a more or less wooded environment in some of the southernmost Regions of Mediterranean Europe. In the Alta Murgia, wooded patches are restricted to the bottom of karst valleys (locally called lame) and hollows (doline), and only at lower altitude. Elsewhere semi-natural grasslands, with sparse shrubs or Pyrus spinose trees, are the dominant landscape element over a large area (Terzi and Marvulli, 2006). Bianco (1962) interpreted these grasslands as a paraclimax, originated from the degradation of pre-existing woods. However, if forests represented the latest stage of the succession, the recolonisation by woody plants would require a very long time period, being limited by poor soils, bioclimatic conditions, and disturbance regime (Forte et al., 2005). As a consequence, the percentages of phanerophytes recorded in our samples were low both in semi-natural rocky grasslands and in former cultivated lands, even after 15 years of abandonment (Table 2).

The percentage of annual plants, although higher for the cluster $\mathrm{Cr}$, remains high also in the semi-natural grasslands, according to other studies concerning this vegetation type in S-Italy (Forte et al., 2005; Terzi and D'Amico, 2016). The percentage of therophytes in Mediterranean grasslands has been correlated to disturbances, such as grazing, or to bioclimate, in particular to summer drought intensity (Madon and Medàil, 1997; Osem et al., 2004; Clary, 2008). Both these conditions, (extensive) grazing and intense summer drought, characterise the semi natural grasslands of Alta Murgia (Forte et al., 2005).

As regards diversity indexes, our results showed a lower species richness on former arable lands compared with rocky grasslands. Similar findings were reported for old-field succession on gypsum outcrops in Toledo (Spain) and in re-development of Mediterranean steppe from old-fields in Crau (France; Römermann et al., 2005; Martínez-Duro et al., 2010). Although we found a similar pathway, a greater number of samples would be required to clearly confirm these findings also for our study area.

It must be stressed that, differently from most of the papers

Table 2. Life-forms spectra, richness, diversity-Shannon index, syntaxonomic index, phytogeographical index and pastoral value of the samples grouped per cluster.

\begin{tabular}{|c|c|c|c|c|c|c|c|c|c|c|c|}
\hline \multirow[t]{2}{*}{ Clusters } & \multirow[t]{2}{*}{ Samples } & \multicolumn{5}{|c|}{ Life forms (\%) } & \multirow[t]{2}{*}{ Richness (n) } & \multirow{2}{*}{$\begin{array}{l}\text { Shannon } \\
\text { index (n) }\end{array}$} & \multirow{2}{*}{$\begin{array}{l}\text { Syntaxonomic } \\
\text { index (\%) }\end{array}$} & \multirow{2}{*}{$\begin{array}{c}\text { Phytogeographical } \\
\text { index }(\%)\end{array}$} & \multirow{2}{*}{$\begin{array}{c}\text { Pastoral } \\
\text { value }(\%)\end{array}$} \\
\hline & & $\mathrm{Ch}$ & G & H & $\mathbf{P}$ & $\mathrm{T}$ & & & & & \\
\hline $\mathrm{Cr}$ & $\begin{array}{c}\text { C3 } \\
\text { C4a } \\
\text { C4b } \\
\text { C5 }\end{array}$ & $\begin{array}{l}1.8 \\
0.0 \\
1.4 \\
0.0\end{array}$ & $\begin{array}{l}3.6 \\
3.0 \\
5.5 \\
2.7\end{array}$ & $\begin{array}{l}42.9 \\
27.3 \\
30.1 \\
30.7\end{array}$ & $\begin{array}{l}1.8 \\
0.0 \\
0.0 \\
0.0\end{array}$ & $\begin{array}{l}50.0 \\
69.7 \\
63.0 \\
66.7\end{array}$ & $\begin{array}{l}56 \\
66 \\
73 \\
75\end{array}$ & $\begin{array}{l}3.9 \\
4.1 \\
4.2 \\
4.2\end{array}$ & $\begin{array}{c}10.7 \\
2.6 \\
19.0 \\
7.8\end{array}$ & $\begin{array}{c}1.7 \\
6.9 \\
0.2 \\
19.5\end{array}$ & $\begin{array}{l}31.4 \\
51.2 \\
46.0 \\
37.7\end{array}$ \\
\hline Co & $\begin{array}{c}\mathrm{Cl} 2 \\
\mathrm{C} 15 \mathrm{a} \\
\mathrm{C} 15 \mathrm{~b}\end{array}$ & $\begin{array}{l}3.8 \\
2.3 \\
1.6\end{array}$ & $\begin{array}{l}5.1 \\
4.7 \\
4.9\end{array}$ & $\begin{array}{l}35.9 \\
39.5 \\
31.1\end{array}$ & $\begin{array}{l}2.6 \\
1.2 \\
0.0\end{array}$ & $\begin{array}{l}52.6 \\
52.3 \\
62.3\end{array}$ & $\begin{array}{l}78 \\
86 \\
61\end{array}$ & $\begin{array}{l}4.3 \\
4.4 \\
4.0\end{array}$ & $\begin{array}{l}11.4 \\
21.7 \\
15.9\end{array}$ & $\begin{array}{l}0.2 \\
1.0 \\
1.2\end{array}$ & $\begin{array}{l}47.3 \\
24.0 \\
32.3\end{array}$ \\
\hline $\mathrm{A}$ & $\begin{array}{l}\mathrm{Aa} \\
\mathrm{Ab}\end{array}$ & $\begin{array}{l}2.7 \\
2.4\end{array}$ & $\begin{array}{c}9.5 \\
14.6\end{array}$ & $\begin{array}{l}35.1 \\
25.6\end{array}$ & $\begin{array}{l}1.4 \\
0.0\end{array}$ & $\begin{array}{l}51.4 \\
57.3\end{array}$ & $\begin{array}{l}74 \\
82\end{array}$ & $\begin{array}{l}4.2 \\
4.3\end{array}$ & $\begin{array}{l}42.0 \\
42.4\end{array}$ & $\begin{array}{l}43.7 \\
35.4\end{array}$ & $\begin{array}{l}30.6 \\
28.9\end{array}$ \\
\hline $\mathrm{G}$ & $\begin{array}{l}\mathrm{Ga} \\
\mathrm{Gb} \\
\mathrm{Gc} \\
\mathrm{Gd} \\
\mathrm{Ge}\end{array}$ & $\begin{array}{l}4.9 \\
3.8 \\
3.8 \\
3.9 \\
3.9\end{array}$ & $\begin{array}{l}3.7 \\
3.8 \\
6.3 \\
9.2 \\
9.2\end{array}$ & $\begin{array}{l}34.6 \\
38.8 \\
27.8 \\
32.9 \\
25.0\end{array}$ & $\begin{array}{l}0.0 \\
0.0 \\
2.5 \\
2.6 \\
2.6\end{array}$ & $\begin{array}{l}56.8 \\
53.8 \\
59.5 \\
51.3 \\
59.2\end{array}$ & $\begin{array}{l}81 \\
80 \\
79 \\
76 \\
76\end{array}$ & $\begin{array}{l}4.3 \\
4.3 \\
4.3 \\
4.2 \\
4.3\end{array}$ & $\begin{array}{l}58.3 \\
45.6 \\
58.1 \\
67.4 \\
69.9\end{array}$ & $\begin{array}{l}25.6 \\
28.8 \\
10.0 \\
33.0 \\
25.6\end{array}$ & $\begin{array}{l}30.5 \\
34.3 \\
20.6 \\
34.5 \\
23.6\end{array}$ \\
\hline
\end{tabular}

$\mathrm{Cr}$, former arable lands, derived from semi-natural grasslands, converted into arable lands by stone crushing, and no longer ploughed or sown for 3-5 years; Co, former arable lands, derived from semi-natural grasslands through stone crushing, and no longer ploughed or sown for 12-15 years; A, ancient former arable lands, manually cleared from stones, that were been taken out of crop production for more than fifty years; $\mathrm{G}$, Mediterranean semi-natural rocky grasslands; Ch, chamaephytes; G, geophytes; H, hemycriptophytes; P, phanerophytes; T, therophytes. 
concerning old-field succession, we considered a particular case of land transformation (by crushing the calcareous rocky substrate with powerful machineries) that completely change the soil profiles and properties (Canora et al., 2008). Moreover, richness dynamic during succession differs in many respects depending on the starting point, if represented by former arable lands or seminatural grasslands (Prévosto et al., 2011; Plieninger et al., 2014). Therefore, our results are not fully comparable with most of other studies.

From a qualitative point of view, many differences among the three main clusters $(\mathrm{Cr}, \mathrm{Co}$ and $\mathrm{A}+\mathrm{G})$ can be pointed out. The dominant taxa of the cluster $\mathrm{Cr}$ were Dasypyrum villosum, Lolium perenne, Trifolium stellatum, Onopordum illyricum, Avena barbata, Crepis neglecta subsp. corymbosa and Trifolium incarnatum subsp. molinerii. These taxa are widespread in disturbed habitats. After 12-15 years from the stopping of cultivations, the taxa with the highest cover value turned out to be Stipa capensis, Avena barbata, Trifolium stellatum, Crepis rubra, Anisantha madritensis. The situation changes in the remaining two sub-clusters ( $G$ and $A$ ) where dominants comprise some taxa typical of this type of grasslands. In the ancient traditional cultivated lands, the dominant species were Stipa austroitalica subsp. austroitalica, Aegilops geniculata, Scorzonera villosa subsp. columnae, Dactylis glomer$a t a$, while in the semi-natural rocky grasslands the dominant species were Asphodelus ramosus subsp. ramosus, Aegilops geniculata, Stipa austroitalica, Dasypyrum villosum, Thymus spinulosus, Scorzonera villosa subsp. columnae, Trachynia distachya, Dactylis glomerata and Eryngium campestre. The sporadic occurrence of some species with high cover, such as Onopordum illyricum $\mathrm{L}$. in sample C3 or Stipa capensis in $\mathrm{C} 15 \mathrm{a} / \mathrm{b}$, indicates the influence of other local factors that still need to be investigated.

Therefore, along the gradient represented by the three main clusters, from $\mathrm{Cr}$ to $\mathrm{AG}$, there was an increasing occurrences of character or differential taxa of the Hippocrepido-Stipion, such as Stipa austroitalica, Scorzonera villosa or Thymus spinulosus which are absent or rare in former arable lands, even after 15 years from stopping cultivation. These results are clearly expressed by the DT index, which, as expected, turned out to be the highest for the rocky pastures with few differences from ancient traditional cultivated lands. Former arable lands obtained by crushing of the karst surface, yielded low values indicating that also after 15 years the floristic composition has not recovered that of semi-natural grasslands. A similar trend was observed for the ER index, showing that the abandonment of cultivation on former arable lands obtained by crushing the rocky substrate, does not provide suitable habitat for conservation of biodiversity, at least up to 15 years of abandonment (Table 2).

The total percent cover values (Appendix Table 1) showed a large variability among samples, yielding high values also in former arable lands. As expected, even after a short period from stopping cultivation, the soil is covered by a dense vegetation as in semi-natural grasslands. The outcropping of rocks may reduce the total percent cover value in semi-natural grasslands, as it is the case of the sample Ge.

The pastoral value (Table 2) was affected by the floristic composition. It varied between 24.0 and $51.2 \%$ in the former arable lands (C3-C15), while in the other sites this value was lower and resulted between $20.6 \%(\mathrm{Gc})$ and $34.5 \%(\mathrm{Gd})$. The pastoral value turned out to be higher in former arable fields (especially in cluster $\mathrm{Cr}$ ) than in rocky pastures, due to the high proportion of excellent, very good and good forage plants, as indicated by the Specific Index (Appendix Table 1). Therophytes - that turned out to be more frequent and abundant in former arable lands - are usually charaterised by some features, such as high productivity, palatability, digestibility, absence of lignified organs (cf. Roggero et al., 2002), that make the Specific Index higher.

Some exceptions to the general trend were found in three sites due to a dense presence of species with scarce grazing value such as Stipa capensis and Anisantha madritensis in the C15 sites or Onopordum illyricum and Dasypyrum villosum in the youngest former arable fields (C3). Within the species with the highest forage quality, the elevate contribute of Lolium perenne and Trifolium incarnatum allowed to an high pastoral value in the four years old former arable lands even though, in these sites, a dense presence of Dasypyrum villosum was detected. The spontaneous presence of Trifolium incarnatum, a forage crop commonly cultivated in the area in rotation with cereals, could have been provided by residual seed bank of previous and/or surrounding cultivations.

The landscape structure, and in particular the semi natural elements, has been proved to affect the biodiversity in the agricultural landscapes and secondary succession on old fields. In our case, the evaluation of the main land-uses in the area surroundings the samples (Table 1) did not reveal appreciable differences among the three clusters of samples with two exceptions. Rural buildings and roads have higher cover percentage near the samples of the cluster $\mathrm{Co}$ while cluster $\mathrm{Cr}$ has higher percentage of abandoned lands (Figure 6). The semi-natural pastures constitutes the dominant element of the landscape around all the samples, except for $\mathrm{Aa}$ and $\mathrm{Ab}$ where they are replaced by the floristically equivalent quote landuse. Therefore, these grasslands can act as source of propagules affecting the colonisation processes on abandoned croplands. For this reason, species of the Hippocrepido-Stipion were recorded also in the samples of the clusters $\mathrm{Cr}$ and $\mathrm{Co}$ although they were more numerous and more abundant in the cluster AG. These results highlighted the importance of safeguarding the remaining rocky grasslands with unmodified soil profile.

\section{Conclusions}

This study showed an important difference between semi-natural rocky grasslands and former arable lands whose rocky substrate had been crushed. Even after 15 years, the vegetation did not recover the floristic composition of semi-natural grasslands. Although it cannot be excluded that, in a much longer period, differences will be smoothed, the crushing of the karst surface remains an important factor affecting biodiversity. Pastures on lands used for traditional farming (quote), characterised by low energy inputs, does not show appreciable differences from seminatural dry grasslands and conserve many taxa of high phytogeographical and conservation value. From a conservation perspective, these results emphasise the need for safeguarding the rocky substrates and their remnant typical grassland communities, even in the so-called quote.

On the other hand, sites originated from the conversion of rocky pastures by stone clearing and crushing of the karst surface showed a remarkable plant cover from the early years of not cultivation and higher pastoral value. Despite the low conservation value, this plant cover provides soil protection from degradation, carbon sequestration and has a higher or at least similar pastoral value than semi-natural grasslands. Hence, former arable lands are valuable natural resources to sustain extensive pastoralism and are able to supply a wide range of ecosystem services. These results will be useful for planning a sustainable development of the Park area taking into account the role of those lands whose rocky sub- 
strate had been already crushed.

In this paper several other factors, such as grazing pressure or occurrences of occasional fire were not taken into consideration even though they might affect not only plant richness but also vegetation recovery and dynamics (Bonet and Pausas, 2007). Thus, a remaining question regards the ecological fate of fields originated from various kinds of land-use modifications, under different grazing pressures or fire disturbances.

\section{References}

Alta Murgia National Park Authority, 2014. Plan and regulation of Alta Murgia National Park. Available from: http://www.parcoaltamurgia.gov.it

Amico A, 1954. Fitostoria descrittiva della provincia di Bari. Istituto di botanica dell'Università di Bari, Bari, Italy.

Andersen E, Baldock D, Bennet H, Beaufoy G, Bignal E, Brower F, Elbersen B, Eiden G, Godeschalk F, Jones G, McCracken DI, Nieuwenhuizen W, van Eupen M, Hennekes S, Zervas G, 2003. Developing a high nature value farming area indicator. European Environment Agency, Copenhagen, Denmark.

Bagella S, Roggero PP, 2004. Integrating phytosociological and agronomic analysis to support the sustainable management of Mediterranean grasslands. Fitosociologia 41(Suppl.1):101-7.

Bianco P, 1962. Flora e vegetazione delle Murge di Nord-Ovest. Università di Bari, Bari, Italy.

Bonet A, Pausas JG, 2007. Old field dynamics on the dry side of the Mediterranean Basin: Patterns and processes in semiarid Southeast Spain. In: Cramer V.A., Hobbs R.J. (eds.) Old fields: dynamics and restoration of abandoned farmland, pp. 247-264. Island Press, Washington, DC, Italy.

Braun-Blanquet J, 1932. Plant sociology. McGraw-Hill, New York, NY, USA.

Bugalho MN, Abreu JMF, 2008. The multifunctional role of grasslands. In: Porqueddu C. (ed.), Tavares de Sousa M.M. (eds.). Sustainable Mediterranean grasslands and their multi-functions. CIHEAM, Zaragoza, Spain. Available from: om.ciheam. org/om/pdf/a79/00800611.pdf

Canora F, Fidelibus MD, Sciortino A, Spilotro G, 2008. Variation of infiltration rate through karstic surfaces due to land use changes: a case study in Murgia (SE-Italy). Eng. Geol. 99:21027.

Canora F, Fidelibus MD, Spilotro G, 2009. Natural and induced endoreic hydrological conditions in the Alta Murgia karstic region (Apulia, Southern Italy). In: EGU General Assembly Conference Abstracts 11:10916.

Castoro P, Creanza A, Perrone N, 1997. Alta Murgia: natura, storia, immagini. Torre di Nebbia, Altamura, Bari, Italy.

Clary J, 2008. Rainfall seasonality determines annual/perennial grass balance in vegetation of Mediterranean Iberian. Plant. Ecol. 195:13-20.

Conti F, Abbate G, Alessandrini A, Blasi C, 2005. An annotated checklist of the Italian vascular flora. Dipartimento di Biologia Vegetale, Università degli Studi di Roma "La Sapienza", Rome, Italy.

Daget P, Poissonet T, 1969. Analyse phytologique des praisies. INRA, Paris, France.

Debussche M, Escarré J, Lepart J, Houssard C, Lavorel S, 1996. Changes in Mediterranean plant succession: old-fields revisited. J. Veg. Sci. 7:519-26.

Euro+Med, 2006. Euro+Med PlantBase: the information resource for Euro-Mediterranean plant diversity. Available from: http://ww2.bgbm.org/EuroPlusMed/

European Commission, 1992. Council Directive of 21 May 1992 on the conservation of natural habitats and of wild fauna and flora, 92/43/EEC. In: Official Journal, L 206, 22/07/1992, pp. $7-50$.

European Commission, 2011. Proposal for a regulation of the European parliament and of the council establishing rules for direct payments to farmers under support schemes within the framework of the common agricultural policy. European Commission, Brussels, Belgium.

European Commission, 2012. Europe in figures: Eurostat yearbook. Available from: http://ec.europa.eu/eurostat/statisticsexplained/index.php/Europe_in_figures_-_Eurostat_yearbook

European Commission, 2016. Farm structure survey 2013 - main results. Available from: http://ec.europa.eu/eurostat/statisticsexplained/index.php/Farm_structure_survey_2013_main_results

FAO, $200 \overline{6}$. Guidelines for profile description, 4th ed. FAO, Rome, Italy

Forte L, Perrino E, Terzi M, 2005. Le praterie a Stipa austroitalica Martinovsky ssp. austroitalica dell'Alta Murgia (Puglia) e della Murgia Materana (Basilicata). Fitosociologia 42:83-103.

Forte L, Vita F, 1999. Variazione del valore agronomico di un pascolo dell'Alta Murgia (Puglia) in funzione dei principali fattori ambientali. Atti Relaz. Accad. Pugliese Sci. 5:131-49.

Fracchiolla M, Tedone L, 2009. Indagini preliminari sulla flora spontanea in ex-coltivi della Murgia Nord-Occidentale. Ital. J. Agron./Rivista di Agronomia 4:(Suppl.4):935-42.

Giglio G, Moretti M, Tropeano M, 1996. Rapporto fra uso del suolo ed erosione nelle Murge Alte: effetti del miglioramento fondiario mediante pratiche di "spietramento". Geol. Appl. Idrogeol. 31:179-85.

Habel JC, Dengler J, Janišová M, Török, Wellstein C, Wiezik M, 2013. European grassland ecosystems: threatened hotspots of biodiversity. Biodivers. Conserv. 22:2131-8.

Hopkins A, 2009. Relevance and functionality of semi-natural grassland in Europe -status quo and future prospective. Report of the International Workshop of the SALVERE-Project 2009. Agricultural Research and Education Centre RaumbergGumpenstein, Irdning, Austria.

Huyghe C, De Vliegher A, Van Gils B, Peeters A, 2014. Grasslands and herbivore production in Europe and effects of common policies. Quae ed., Versailles, France.

Janišová M, Bartha S, Kiehl K, Dengler J, 2011. Advances in the conservation of dry grasslands: introduction to contributions from the seventh European Dry Grassland Meeting. Plant Biosyst. 145:507-13.

Kaligarič M, Culiberg M, Kramberger B, 2006. Recent vegetation history of the North Adriatic grasslands: expansion and decay of an anthropogenic habitat. Folia Geobot. 41:241-58.

Keenleyside C, Beaufoy G, Tucker G, Jones G, 2014. High nature value farming throughout EU-27 and its financial support under the CAP. Institute for European Environmental Policy, London, UK. Available from: http://ec.europa.eu/environment/agriculture/pdf/High\%20Nature\%20Value\%20farming.pdf

Macchia F, Cavallaro V, Forte L, Terzi M, 2000. Vegetazione e clima della Puglia. Cah. Opt. Méditer. 53:29-49.

Madon O, Médail F, 1997. The ecological significance of annuals on a Mediterranean grassland (Mt Ventoux, France). Plant Ecol. 129:189-99.

Martínez-Duro E, Ferrandis P, Escudero A, Luzuriaga AL, Herranz JM, 2010. Secondary old-field succession in an ecosystem 
with restrictive soils: does time from abandonment matter? Appl. Veg. Sci. 13:234-48.

McCune B, Grace JB, 2002. Analysis of ecological communities. MjM Software, Gleneden Beach, OR, USA.

Mccune B, Mefford M J, 2011. PC-ORD. Multivariate analysis of ecological data. Version 6.19 MjM Software, Gleneden Beach, OT, USA.

Moretti M, De Boni A, Roma R, Fracchiolla M, Van Passel S, 2016. Integrated assessment of agro-ecological systems: the case study of the "Alta Murgia" National park in Italy. Agr. Syst. 144:144-55.

Moretti M, Fiore A, Pieri P, Tropeano M, Valletta S, 2004. Effetti dei "miglioramenti fondiari" nelle Murge Alte (Puglia): l'impatto antropico sul paesaggio carsico e costiero. Ital. J. Quatern. Sci. 17:323-30.

Mueller-Dombois D, Ellenberg D, 1974. Aims and methods of vegetation ecology. Wiley, New York, NY, USA.

Osem Y, Perevolotsky A, Kigel J, 2004. Site productivity and plant size explain the response of annual species to grazing exclusion in a Mediterranean semi冈arid rangeland. J. Ecol. 92:297309.

Ostermann OP, 1998. The need for management of nature conservation sites designated under Natura 2000. J. Appl. Logic 35:968-73.

Paracchini ML, Petersen JE, Hoogeveen Y, Bamps C, Burfield I, van Swaay C, 2008. High nature value farmland in Europe: an estimate of the distribution patterns on the basis of land cover and biodiversity data. European Commission, Joint Research Centre, Institute for Environment and Sustainability, Brussels, Belgium.

Parise M, 2012. Management of water resources in karst environments, and negative effects of land use changes in the Murge Area (Apulia, Italy). Karst Develop. 2:17-8.

Pärtel M, Bruun HH, Sammul M, 2005. Biodiversity in temperate European grasslands: origin and conservation. In: Integrating Efficient Grassland Farming and Biodiversity: Proceedings of the 13th International Occasional Symposium of the European Grassland Federation 10:1-14.

Perrino EV, Wagensommer RP, 2013. Habitats of Directive 92/43/EEC in the National Park of Alta Murgia (ApuliaSouthern Italy): threat, action and relationships with plant communities. J. Environ. Sci. Eng. A 2:229-35.

Perrino P, Laghetti G, Terzi M, 2006. Modern concepts for the sustainable use of Plant Genetic Resources in the Mediterranean natural protected areas: the case study of the Alta Murgia Park (Italy). Genet. Resour. Crop. Ev. 53:695-710.

Pignatti S, 1982. Flora d'Italia. Ed. Agricole, Bologna, Italy.

Pirini CB, Tsiripidis I, Bergmeier E, 2014. Steppe-like grassland vegetation in the hills around the lakes of Vegoritida and Petron, north-central Greece. Hacquetia 13:121-70.

Plieninger T, Hui C, Gaertner M, Huntsinger L, 2014. The impact of land abandonment on species richness and abundance in the Mediterranean Basin: a meta-analysis. PLoS One 9:e98355:112.

Prévosto B, Kuiters L, Bernhardt-Römermann M, Dölle M, Schmidt W, Hoffmann M, Uytvanck J Van, Bohner A, Kreiner D, Stadler J, Klotz S, Brandl R, 2011. Impacts of land abandonment on vegetation: successional pathways in European habitats. Folia Geobot. 46:303-25.

Ricchetti G, Ciaranfi N, Luperto Sinni E, Mongelli F, Pieri P, 1988. Geodinamica ed evoluzione sedimentaria e tettonica dell'Avampaese Apulo. Mem. Soc. Geol. It. 41:57-82.

Rivas Martinez S, 2008. Global bioclimatics (Clasificación Bioclimática de la Tierra). Available from: http://www.globalbioclimatics.org/book/bioc/global_bioclimatics2008 00.htm\#srm

Rodwell JS, Schaminée JHJ, Mucina L, Pignatti S, Dring J, Moss D, 2002. The diversity of European vegetation. An overview of phytosociological alliances and their relationships to EUNIS habitats. National Reference Centre for Agriculture, Nature and Fisheries, Amsterdam, The Netherlands.

Roggero PP, Bagella S, Farina R, 2002. Un archivio dati di indici specifici per la valutazione integrata del valore pastorale. Riv. Agron. 36:149-56.

Römermann C, Dutoit T, Poschlod P, Buisson E, 2005. Influence of former cultivation on the unique Mediterranean steppe of France and consequences for conservation management. Biol. Conserv. 121:21-33.

Schwaiger E, Banko G, Brodsky UL, van Doorn A, Alterra, 2012. Updated high nature value farmland in Europe. An estimate of the distribution patterns on the basis of CORINE Land Cover 2006 and biodiversity data. Available from: http://www. eea.europa.eu/data-and-maps/data/high-nature-value-farmland/further-documentation/hnv-farmland-in-europe2012.pdf/download

Silva JP, Toland J, Jones W, Eldridge J, Thorpe E, O'Hara E, 2008. LIFE and Europe's grasslands: restoring a forgotten habitat. DG environment of the EU (LIFE unit-E4). Available from: https://publications.europa.eu/it/publication-detail/-/publication/8e0c4fc5-c89c-491b-b61c-d2f499174d25

Smit HJ, Metzger MJ, Ewert F, 2008. Spatial distribution of grassland productivity and land use in Europe. Agric. Syst. 98:208-19.

Terzi M, D'Amico, FS, 2016. Dry grasslands of Hippocrepido glaucae-Stipion austroitalicae in the Pollino Massif (Calabria, Italy). Acta Bot. Croat. 75:89-98.

Terzi M, Di Pietro R, D’Amico FS, 2010. Analisi delle specie indicatrici applicata alle comunità a Stipa austroitalica Martinovsky e relative problematiche sintassonomiche. Fitosociologia 47:3-28.

Terzi M, Marvulli M, 2006. Priority zones for Mediterranean protected agro-sylvo-pastoral landscapes. Ecol. Medit. 32:29-38.

van der Maabel E, 1979. Transformation of cover-abundance values in phytosociology and its effects on community similarity. Vegetatio 39:97-114.

Veen P, Jefferson R, Smidt JD, Straaten J, 2009. Grasslands in Europe of high nature value. KNNV Publishig, Amsterdam, The Netherlands.

Vrahnakis M, Janisová M, Rusina S, Török P, Venn S, Dengler J, 2013. The European Dry Grassland Group (EDGG): stewarding Europe's most diverse habitat type. In: H. Baumbach (ed.) Steppenlebensräume Europas - Gefährdung, Erhaltungsmassnahmen und Schutz. EU-LIFE-Projekt Erhaltung und Entwicklung der Steppenrasen Thüringens, pp. 417-434.: Thüringer Ministerium für Landwirtschaften, Forsten, Umwelt und Naturchutz, Erfurt, Germany. 